\section{Myelopathy associated with human $T$ cell lymphotropic virus type 1 in a white European native to England}

\author{
Amza Ali, Peter Rudge
}

Clinical Research Centre, Harrow HA1 3UJ Amza Ali, British Council scholar

National Hospital for Neurology and Neurosurgery, Queen Square, London WCIN 3BG

Peter Rudge, consultant neurologist

Correspondence to: Dr Rudge.

BMF 1992;305:453 lumbar pain, and sphincter involvement.
Tropical spastic paraparesis is now a well recognised clinical entity and thought in most cases to be due to infection with human $\mathrm{T}$ cell lymphotropic virus type 1 , the first discovered human retrovirus. ' People of AfroCaribbean or Japanese origin represent the primary groups at risk in view of the high prevalence of the virus in these populations, and series of patients with tropical spastic paraparesis born in the Caribbean but now living in Europe, especially France and the United Kingdom, have been described. ${ }^{2}$ The clinical presentation is of slowly progressive spastic paraparesis,

Tropical spastic paraparesis is rare in patients of white origin in Europe who have no risk factors for human $\mathrm{T}$ cell lymphotropic virus type 1 infectionnamely, drug addiction, blood transfusion, and sexual contact with Afro-Caribbeans. Two cases of tropical spastic paraparesis have been reported from continental Europe. We describe the first case in a British resident who has never left the United Kingdom.

\section{Case report}

A 57 year old, right handed, white, female, retired school cleaner with no family history of neurological disease presented with a six month history of progressive sensory disturbance and weakness of the lower limbs, accompanied by occasional urinary incontinence and back pain. She had been married for 30 years to a white man, who was born in London, and had never been abroad; she had one daughter.

On examination her corrected visual acuity was $6 / 6$ on the right and $6 / 12$ on the left. There was no other abnormality of the cranial nerves. In the upper limbs tone was increased on the right, but power was normal. There was a moderately severe spastic paraparesis. All the reflexes were brisk and the plantar responses extensor. There was a vague sensory level to pinprick and light touch to the 10th dorsal dermatone bilaterally.

On investigation routine blood count and biochemical test results were normal, as were serum B-12 and folate concentrations. Serological test results for syphilis were negative. The cerebrospinal fluid showed a single IgG oligoclonal band not found in the serum. Computed tomographic myelography and two magnetic resonance scans revealed a slight swelling of the cervical cord without focal disease; there were occasional non-specific lesions in the white matter of the cerebral hemispheres. The visual evoked potentials to a patterned stimulus were symmetrically delayed at $132 \mathrm{~ms}$.

Antibodies to human $\mathrm{T}$ cell lymphotropic virus type 1 were found in the serum by particle agglutination assay (two laboratories) and their specificity was confirmed by enzyme linked immunosorbent assay
(ELISA) at a titre of $10^{-1.5}$. Western blotting revealed significant titres (200) of antibodies to p18, p24, and gp62 antigens of the virus. The polymerase chain reaction with gag and $\mathrm{pX}$ primers also detected the presence of integrated human $\mathrm{T}$ cell lymphotropic virus type 1 proviral DNA in peripheral blood lymphocytes. Her husband was negative for virus antibodies by ELISA; permission was not granted to approach her daughter for testing.

\section{Comment}

The initial diagnosis was the progressive form of multiple sclerosis as the patient was white and had no risk factors for human $\mathrm{T}$ cell lymphotropic virus type 1 infection. However, the clinical findings were equally in keeping with tropical spastic paraparesis. Similarly, the symmetrical delay of the visual evoked potentia and the unimpressive abnormalities on magnetic resonance imaging, with no focal signal return from the cervical cord, are typical of tropical spastic paraparesis. ${ }^{4}$ None of these clinical or laboratory features, however, is sufficient to cast more than marginal doubt on the clinical diagnosis of multiple sclerosis, especially the progressive paraparetic form occurring in older patients.

The demonstration of infection with human $\mathrm{T}$ cell lymphotropic virus type 1 is crucial to the true diagnosis; there is compelling evidence that our patient was infected-namely, detection of specific antibodies on particle agglutination, ELISA, and western blotting and of viral genome with the polymerase chain reaction.

White people are clearly susceptible to virus infection acquired by blood transfusion and intravenous drug abuse; we have shown that white Europeans acquire tropical spastic paraparesis in one area where human $T$ cell lymphotropic virus type 1 is endemicnamely, Brazil. ${ }^{5}$ However, this disease has never been described in a white native of the United Kingdom with no obvious risk factors who has never left the country.

Previous limited studies have pointed to the low rate of seropositivity in the general population in the United Kingdom. It is therefore imperative to ascertain the true seroprevalence in the population, bearing in mind that less than $1 \%$ of seropositive subjects will manifest clinical disease. The implications for the blood transfusion services, especially with older donors in the United Kingdom, are self evident.

We thank Professor C D Marsden for referring this patient to us.

1 Yoshida M, Mivoshi I, Himuma Y. Isolation and characterisation of human adult T-cell leukemia virus and its implication in disease. Proc Natl Acad Sci USA 1982;79:2031-5.

2 Cruickshank JK, Rudge P, Dalgleish G, Newton M, McLean BN, Barnard RO, et al. Tropical spastic paraparesis and human T-cell lymphotropic virus type 1 tal. Tropical spastic paraparesis and human T-cellyr

3 Lugaresi A, Uncini A, Porrini AM, Battista P, French D, Curia MC, et al. HTLV-1 associated myeloneuropathy in an Italian. Acta Neurol Scand 1991;184:186-91.

4 Rudge P, Ali A, Cruickshank JK. Multiple sclerosis, tropical spastic paraparesis and HTLV-1 infection in Afro-Caribbean patients in the United Kingdom. f Neurol Neurosurg Psychiatry 1991;54:689-94.

5 Araujo A, Ali A, Newell A, Dalgleish AG, Rudge P. HTLV-1 infection and neurological disease in Rio de Janeiro. I Neurol Neurosurg Psychiatry 1992;55:153-5

(Accepted 30 fune 1992) 